\title{
Cellular response to alpha-gliadin in untreated coeliac disease
}

\author{
CLIONA O'FARRELLY, C FEIGHERY, J F GREALLY, AND D G WEIR \\ From the Departments of Immunology and Medicine, Trinity College, Dublin, and the Gastroenterology Unit, Sir Patrick \\ Dun's and St. James's Hospitals, Dublin
}

SUMMARY An improved technique for the detection of alpha-gliadin sensitised mononuclear cells in the peripheral blood of untreated coeliac patients is described. This method is a modification of the direct LMIF assay, and involves exposure of lymphocytes to alpha-gliadin and the assay of the resultant lymphokine produced using normal leucocytes as indicator cells. All untreated coeliac patients, 14 of 15 treated patients, and two of 28 controls responded to alpha-gliadin. The direct LMIF assay in comparison is less sensitive, and detected sensitivity to alpha-gliadin in only four out of eight patients with untreated coeliac disease. Use of the indirect LMIF technique demonstrates that in untreated as well as treated coeliac patients there are cells sensitised to alpha-gliadin circulating in the peripheral blood. These findings may have pathogenic and diagnostic significance.

The mechanism of gluten intolerance in coeliac disease is unknown but may be due to an abnormal immunological reaction to wheat proteins. ${ }^{1}$ Patients with untreated coeliac disease have an increased infiltration of lymphocytes in the small intestinal mucosa. ${ }^{2}$ Local antibody-mediated immune reactions have been demonstrated in the mucosa of both children and adults with coeliac disease after a gluten challenge ${ }^{3}$ and cell-mediated immunity to gluten, as measured by blastogenesis, has been found in peripheral blood lymphocytes in the presence of both gluten fraction III $^{4}$ and a subfraction thereof. ${ }^{5}$

The leucocyte migration inhibition factor assay (LMIF assay) has also been used to study cellmediated immune reactions to gluten fractions in patients with coeliac disease. ${ }^{6}$ Antigen induced inhibition of leucocyte migration has been widely accepted as an in vitro correlate of cellular immunity in man. ${ }^{7}$ Cell migration is thought to be inhibited by lymphokines which are the products of antigenlymphocyte interaction. ${ }^{8}$ The extent of migration inhibition depends both on lymphocyte sensitisation and the responsiveness of leucocytes to lymphokines. ${ }^{9}$ Using an LMIF assay $13 \%$ of untreated coeliac patients and $54 \%$ of treated patients were sensitised to gluten fraction III ${ }^{10}$ and $37.5 \%$ and

Received for publication 2 June 1981
$80 \%$ untreated and treated groups respectively to an alpha-gliadin fraction. ${ }^{11}$

Clausen ${ }^{12}$ used cell-free supernatants to assay for LMIF production. This is a more sensitive and easily controllable system than the direct or one step method. The supernatants are obtained from peripheral blood mononuclear cells (PBMC) cultured in the presence of the antigen to be examined and tested against normal indicator cells. The specific reaction of antigen recognition by sensitised PBMC with the subsequent release of lymphokine is the first step and the assay of the lymphokine is the second.

In this study, alpha-gliadin, a wheat protein shown to be toxic to coeliac patients, ${ }^{13}$ was prepared using an ion-exchange chromatographic technique. The specificity of the response to this antigen was assessed using both the direct and indirect LMIF assays.

\section{Methods}

SUBJECTS

Twenty-three patients with adult coeliac disease, of whom 15 were on gluten free diets and eight were untreated, were studied. All had subtotal or severe partial villous atrophy on jejunal biopsy and a clinical response to a gluten free diet of at least one year's duration in the treated patients, and response to the diet after testing in the untreated group. All the coeliac patients on gluten free diets attended the 
coeliac clinic regularly on a three month basis and were interviewed by a dietician. If any patient appeared not be be adhering to the diet, he was excluded from the study.

Control groups included 15 healthy laboratory staff and 15 patients with inflammatory bowel disease of whom seven had Crohn's disease and six had ulcerative colitis. None of the former control group was biopsied and of the latter group all had confirmatory histology of the lesion and six had small intestinal histology which excluded coeliac disease. In the remainder no clinical or laboratory feature pointed to anything other than inflammatory bowel disease.

\section{DIRECT LMIF ASSAY}

The direct assay was carried out according to Haeney and Asquith. ${ }^{11}$ The results are expressed as migration indices (MI) which were derived as follows:

$$
\text { Mî } \frac{\begin{array}{l}
\text { Mean (of 3) migration area in antigen } \\
\text { containing medium }
\end{array}}{\text { Mean (of 3) migration area in medium alone }}
$$

\section{INDIRECT LMIF ASSAY}

Heparinised venous blood diluted 1:2 in Hank's balanced salt solution (HBSS, Gibco Biocult), was layered onto a Ficoll-paque gradient (Pharmacia, Uppsala). After centrifugation at 1200 RPM for 35 minutes the mononuclear cells (PBMC) found at the interface were removed and washed twice with HBSS. The cells were finally resuspended at a concentration of $1 \times 10^{6}$ cells $/ \mathrm{ml}$ of medium in RPMI (Gibco Biocult) containing $10 \%$ fetal calf serum and $10 \mathrm{mN}$ Hepes's buffer, $\mathrm{pH} \mathrm{7 \cdot 3}$. Aliquots containing $1 \mathrm{ml}$ of cell suspension were dispensed into upright plastic culture tubes with or without $1 \mu \mathrm{g} / \mathrm{ml}$ alpha-gliadin. Cultures were incubated for 72 hours at $37^{\circ} \mathrm{C}$. in a $5 \% \mathrm{CO}_{2}$ water-saturated atmosphere. At the end of the incubation period, the cell suspensions were centrifuged at $2000 \mathrm{rpm}$. The supernatants were harvested and diluted 1:2 with fresh RPMI. The unstimulated culture supernatants were reconstituted with appropriate concentrations of antigen, before testing for the presence of LMIF.

Leucocyte suspensions from healthy donors served as indicators for LMIF activity in the supernatants. The technique used was similar to that of the direct LMIF assay.

\section{PREPARATION OF ANTIGEN}

Gliadin was prepared according to Eterman et al. ${ }^{14}$ using milled Irish flour. The wheat protein was further processed using a modification of an ionexchange chromatographic technique. ${ }^{15}$ A column
$15 \times 5 \mathrm{~cm}$ was packed with carboxy-methylcellulose, Whatman, CM52, and buffered to $\mathrm{pH} 4.2$ with eluant $(0.005 \mathrm{M}$ sodium acetate buffer). The flow rate was adjusted to $150 \mathrm{ml} /$ hour. One gram of lyophylised gliadin resuspended in $100 \mathrm{ml}$ of buffer was applied to the column. A stepped gradient of sodium chloride in the sodium acetate buffer was used to elute the different fractions. Six fractions were obtained. These were concentrated using a rotary film evaporator, dialysed extensively to remove the salt, and then lyophylised. The eluate obtained with a sodium chloride concentration of $0.09 \mathrm{M}$ corresponded to the alpha gliadin used by other workers (Hekkens, personal communication).

It was found that $1 \mathrm{mg} / \mathrm{ml}$ of medium gave optimum results in the direct LMIF assay and $1 \mu \mathrm{g} / \mathrm{ml}$ in the indirect assay.

\section{STATISTICS}

As the data were normally distributed, Student's $t$ test for unpaired data was used to analyse the results.

\section{Results}

\section{DIRECT LMIF ASSAY (Fig. 1)}

The mean MI of leucocytes isolated from treated coeliac patients when tested in the presence of alpha gliadin was $0.42 \pm 0.12 \mathrm{SD}$, from normal individuals was $0.99 \pm 0.08 \mathrm{SD}$, and from patients with noncoeliac disorders was $1 \cdot 02 \pm 0 \cdot 10 \mathrm{SD}$. The difference between the coeliac subjects and the control groups was significant $(\mathrm{P}<0.01)$.

Leucocytes isolated from eight untreated coeliac patients had a mean MI of $0.73 \pm 0.27$ SD (P $>0.05$, when compared with either of the control groups); four were within the normal range and four showed significant inhibition.

\section{INDIRECT LMIF ASSAY (Fig. 2)}

PBMC isolated from treated or untreated patients, cultured in the presence of alpha gliadin released LMIF into the culture medium. These supernatants when compared with the control groups significantly inhibited the migration of normal leucocytes at the $1 \%$ level. The mean MI for treated coeliacs was $0.67 \pm 0.12 \mathrm{SD}$ and for untreated coeliac patients $0.64 \pm 0.10 \mathrm{SD}$; the difference between the treated and untreated groups was not significant. PBMC isolated from treated or untreated coeliac patients and cultured in the absence of alpha-gliadin did not produce any detectable LMIF (mean MI $1.00 \pm 0.08$ and $1.00 \pm 0.03$ respectively). The differences with and without alpha-gliadin for both the treated and untreated groups were highly significant $(P<0.001)$. No LMIF was released into the culture medium by PBMC from normal individuals, irrespective of 


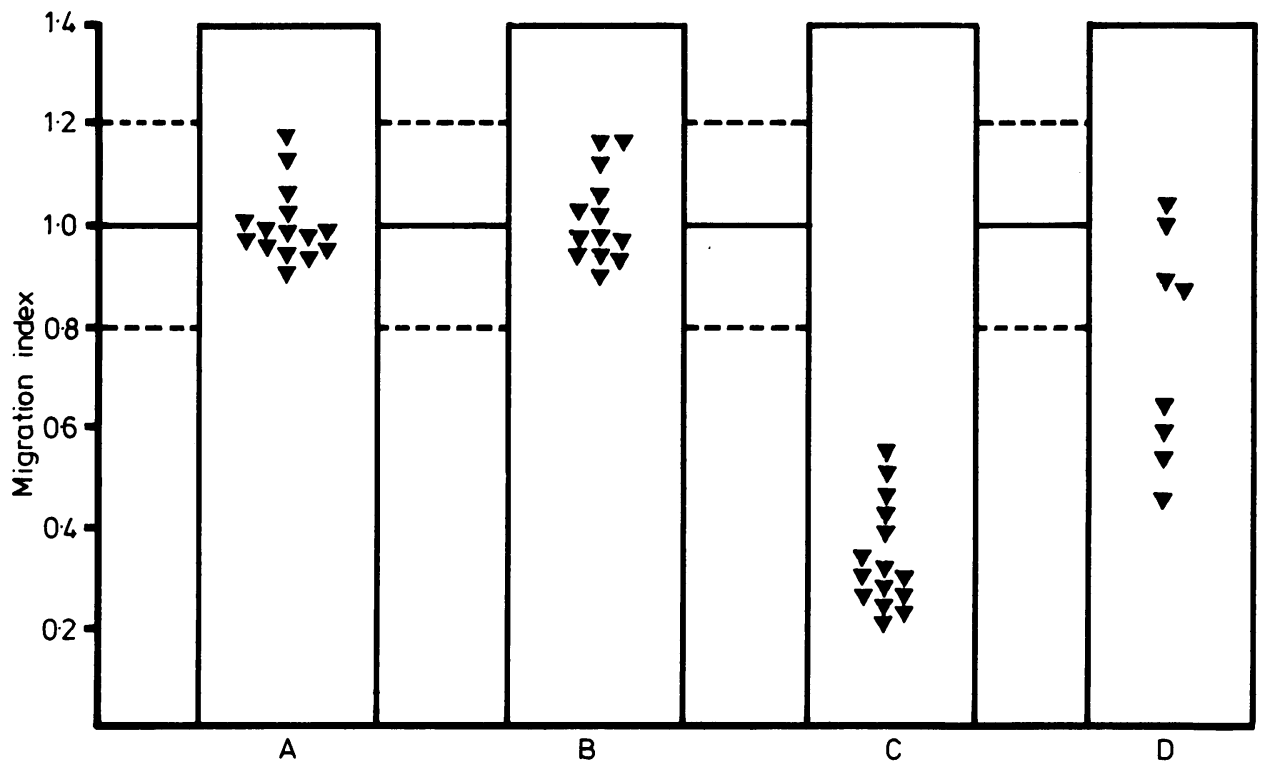

Fig. 1 Direct LMIF assay: effect of $1 \mathrm{mg} / \mathrm{ml}$ alpha gliadin on the migration of leucocytes. A: normal individuals. B: individuals with gastrointestinal disorders other than coeliac disease. $C$ : treated coeliac patients. $D$ : untreated coeliac patients. (Migration indices greater than 1.2 and less than 0.8 represent significant stimulation and inhibition of migration respectively.)

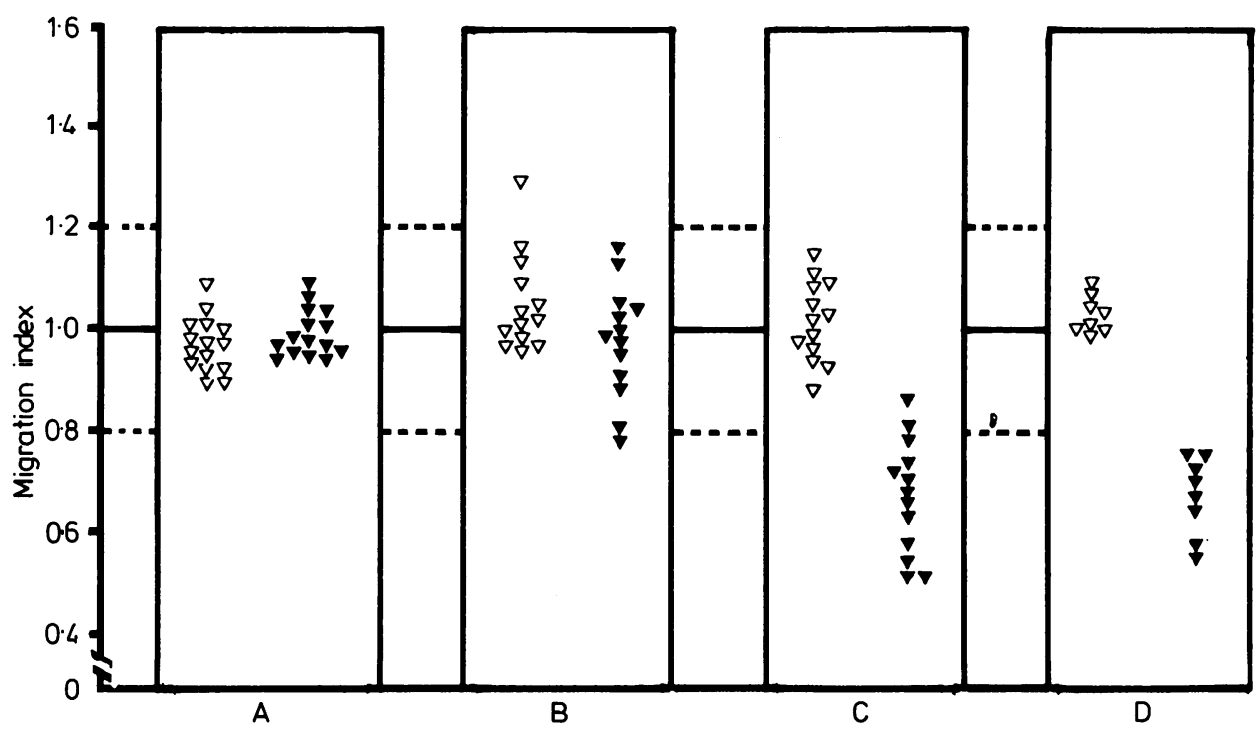

Fig. 2 Indirect LMIF assay: effect of $1 \mu \mathrm{g} / \mathrm{ml}$ alpha-gliadin on the release of LMIF by PBMC into culture supernatant measured by the inhibition of migration of normal leucocytes. $\triangle$ : supernatants from PBMC cultured in the absence of antigen and reconstituted with appropriate concentrations of alpha-gliadin before testing. $\triangle$ : supernatants from PBMC cultured in the presence of alpha-gliadin. A: normal individuals. $B$ : individuals with gastrointestinal disorders other than coeliac disease. $C$ : treated coeliac patients. D: untreated coeliac patients. (Migration indices greater than 1.2 and less than 0.8 represent significant stimulation and depression of migration respectively.) 
whether alpha gliadin was (mean MI $0.97 \pm 0.05$ ) or was not (mean MI $0.99 \pm 0.05$ ) in the culture medium. The mean MI of patients with other gastrointestinal disorders was $1.04 \pm 0.09 \mathrm{SD}$ with and $0 \cdot 95 \pm 0 \cdot 10 \mathrm{SD}$ without alpha-gliadin. The differences between the control groups, with and without alphagliadin, were not significant.

\section{Discussion}

This study confirms the specificity of the response elicited by alpha-gliadin when used as an antigen for direct LMIF assays in treated coeliac patients as shown by others. ${ }^{611}$ Other preparations of wheat protein and casein do not appear to elicit such a specific response (unpublished data). Fourteen of the $15(93 \%)$ coeliac patients on gluten free diets responded to the antigen, while none of the $28(0 \%)$ control subjects showed a reaction. Leucocytes of untreated coeliac patients showed migration inhibition in four out of eight $(50 \%)$, which is similar to the incidence of $37.4 \%$ reported by Haeney and Asquith. ${ }^{11}$ However, the overall value of this test is limited by the high incidence of false negatives.

By contrast, when the indirect assay is used, PBMC from all the untreated and $95 \%$ of the treated coeliac patients produced assayable lymphokine when stimulated by alpha-gliadin, as compared with $15 \%$ of patients with gastrointestinal diseases other than coeliac disease and $0 \%$ of normal controls (histological studies on these patients excluded coeliac disease). This is a distinct improvement in the separation of untreated coeliac patients from the control groups. Also, the indirect LMIF assay is a more sensitive technique in that migration inhibition can be demonstrated at one thousandth the concentration of antigen required for the direct assay.

This study and that of Haeney and Asquith ${ }^{11}$ have shown that when the direct LMIF assay is used, the incidence of detection of alpha gliadin sensitised cells in the peripheral blood is lower in untreated than in treated coeliac patients. It has been suggested ${ }^{4}$ that this may reflect the migration of these cells to the small intestinal mucosa in response to the continuous antigenic challenge of absorbed gliadin. The increased sensitivity of the indirect LMIF assay shows that sensitised cells can still be detected in the peripheral circulation of untreated coeliac patients.

When coeliac patients ingest wheat protein, lymphocytes are attracted to the jejunum and increased numbers are found between the epithelial cells of the mucosa. ${ }^{3}$ When gluten is withdrawn from the diet, the number of these intraepithelial lymphocytes falls. ${ }^{16}$ Ferguson and co-workers ${ }^{17}$ have shown that when biopsy specimens obtained from the small intestine of untreated coeliac patients are cultured with alpha-gliadin they secrete a factor into the culture medium which inhibits the migration of normal leucocytes. They propose that a local cell-mediated response to gliadin causes the villous atrophy and crypt hyperplasia which characterises the coeliac mucosal lesion. This study shows that mononuclear cells obtained from the peripheral blood of untreated coeliac patients also produce a substance which inhibits normal leucocyte migration.

We are grateful to the Medical Research Council of Ireland for financial support during this project.

\section{References}

${ }^{1}$ Housley J, Asquith P, Cook WI. Immune response to gluten in adult coeliac disease. Br Med J 1969; 2:159-61.

${ }^{2}$ Hourihane DO'B. The pathology of malabsorption states. In: Harrison CV, ed. Recent advances in pathology London: Churchill, 1966: 320-47.

${ }^{3}$ Shiner M, Ballard J. Antigen-antibody reactions in jejunal mucosa in childhood coeliac disease after gluten challenge. Lancet 1972; 1:1202-5.

${ }^{4}$ Holmes GKI, Asquith P, Cook WI. Cell-mediated immunity to gluten fraction III in adult coeliac disease. Clin Exp Immunol 1976; 24:259-65.

${ }^{5}$ Sikora F, Anand BS, Truelove SC, Ciclitira PJ, Offord RE. Stimulation of lymphocytes from patients with coeliac disease by a sub-fraction of gluten. Lancet 1976; 2:389-91.

${ }^{\circ}$ Douwes FR, Lippmann-Nielsen I, Hank R. Gliadininduzierte Migrationshemmung peripherer Leukozyten in der Agaroseplattentechnik bei Patienten mit Coeliakie. Dtsch Med Wochenschr 1977; 102:721-4.

${ }^{7}$ Soburg M, Bendixen G. Human lymphocyte migration as a parameter of hypersensitivity. Acta Med Scand 1967; $181: 247-56$.

${ }^{8}$ Dumonde DC, Wolstencroft RA, Panayi GS, Matthew M, Morley J, Howson WI. Non antibody mediators of cellular immunity generated by lymphocyte activation. Nature (Lond) 1969; 224:38-42.

${ }^{9}$ Dumonde DC, Maini RN. The clinical significance of mediators of cellular immunity. Clin Allergy 1971; 1:123-32.

${ }^{10}$ Bullen AW, Losowsky MS. Cell-mediated immunity (CMI) to gluten fraction III (GF III) in adult coeliac disease (ACD). Gut 1976; 17:813.

${ }^{11}$ Haeney MR, Asquith P. In-vitro immunological assay for diagnosis of coeliac disease. Lancet 1978; 1:876.

${ }^{12}$ Clausen JE. Migration inhibitory effect of cell-free supernatants from tuberculin-stimulated cultures of human mononuclear leukocytes demonstrated by two-step MIF agarose assay. J Immunol 1973; 110:546-51.

${ }^{13}$ Hekkens W Th JM, Haex AJ, Willihagen RGJ. Some aspects of gliadin fractionation and testing by a histochemical method. In: Booth CC, Dowling RH, eds. Coeliac disease Edinburgh: Churchill Livingstone 1970: $7-13$.

${ }^{14}$ Eterman KP, Hekkens W Th JM, Peña AS, Lems-Van Kan PH, Feltkamp IEW. Wheat grains: antibodies in 
serum of gluten sensitive patients. $J$ Immunol Methods $1977 ; 14: 85-92$.

${ }^{15}$ Kendall MJ, Schneider R, Cox PS, Hawkins CF. Gluten sub-fractions in coeliac disease. Lancet 1972; 2:1065-7.

${ }^{16}$ Ferguson A, Murray D. Quantitation of intraepithelial lymphocytes in human jejunum. Gut 1971; 12:988-994.

${ }^{17}$ Ferguson A, McClure JP, MacDonald TT, Holden RJ. Cell-mediated immunity to gliadin within the small intestinal mucosa in coeliac disease. Lancet 1975; 1:895-7. 